\title{
Effect of Flow Rate and Length of Gully on Lettuce Plants in Aquaponic and Hydroponic Systems
}

\section{El-Sayed G Khater* and Samir A Ali}

Agricultural Engineering Department-Faculty of Agriculture-Benha University 13736, Egypt

\begin{abstract}
The main objective of this research is to study the effect of source of nutrients, water flow rate and length of gully to know the possibility of producing lettuce plants depending on the nutrients existing in effluent fish farm as compared with the lettuce production using standard nutrient solutions. To achieve that was studied the effect of source of nutrients (effluent fish water and nutrient solution), flow rate $\left(1.0,1.5\right.$ and $\left.2.0 \mathrm{~L} \mathrm{~min}^{-1}\right)$ and length of gully (2, 3 and $4 \mathrm{~m}$ ) on the following parameters: nutrient uptake, dry weight and $\mathrm{NO}_{3}-\mathrm{N}$ content in plant. The obtained results indicated that the fresh and dry weight of shoots increased in nutrient solution over those of effluent fish farm. The fresh and dry weight of shoots decreased with increasing the flow rate and the length of gully. The dry weight of roots increased in nutrient solution over those of effluent fish farm. The dry weight of roots decreased with increasing the flow rate and the length of gully. The $\mathrm{NO}_{3}-\mathrm{N}$ content significantly increased in nutrient solution over those of effluent fish farm. The $\mathrm{NO}_{3}-\mathrm{N}$ content decreased with increasing the flow rate and length of gully. The $\mathrm{NO}_{3} / \mathrm{protein}$ ratio increased in nutrient solution over those of effluent fish farm.
\end{abstract}

Keywords: Aquaponics; Hydroponics; Aquaculture; Fish farm

\section{Introduction}

Aquaponics is the integration of aquaculture (fish farming) and hydroponics (growing plants without soil). In aquaponic system the fish consume food and excrete waste primarily in the form of ammonia. Bacteria convert the ammonia to nitrite and then to nitrate [1-14].

Aquaponics has several advantages over other recirculating aquaculture systems and hydroponic systems that use inorganic nutrient solutions. The hydroponic component serves as a biofilter, and therefore a separate biofilter is not needed as in other recirculating systems. Aquaponic systems have the only biofilter that generates income, which is obtained from the sale of hydroponic produce such as vegetables, herbs and flowers [15]

Small proportion of ammonia is toxic to fish, when as nitrate is not toxic to fish. If nitrate increased over a specific limit it will be toxic to fish eaters (human being) and cause nitrate pollution and the eaters will suffer from methamoglobnia disease. The blood of the affected people became brown and will not be able to carry oxygen to the rest of human organs [16]. To avoid this problem in aquaculture, part of water should be discharged daily and add fresh water instead. Another solution to this problem is establishing hydroponic system attached to the aquaculture and cultivates plants in the hydroponics in order to save discharged-water and gets use of existing nitrate.

Benefits of aquaponics are conservation of water resources and plant nutrients, intensive production of fish protein and reduced operating costs relative to either system in isolation. Water consumption in integrated systems including tilapia production is less than $1 \%$ of the required in pond culture to produce equivalent yields [4].

Lettuce is one of the best crops for aquaponic systems because it can be produced in a short period and, as a consequence, pest pressure is relatively low. Unlike tomato and cucumber, a high proportion of the harvested biomass is edible. With lettuce, income per unit area per unit time is very high. Other fast growing and high income generating crops are herbs such as basil and chive, which are being grown commercially in aquaponic systems [15].

The objective of the current investigation was to study the effect of source of nutrients, water flow rate and length of gully to know the possibility of producing lettuce plants depending on the nutrients existed in effluent fish farm as compared with the lettuce production using standard nutrient solutions.

\section{Materials and Methods}

The experiment was carried out at El-Nenaiea farm, Ashmon, ElMinufiya Governorate, during the period of February to April, 2013.

\section{System description}

Figure 1 illustrates the experimental setup. It shows the recirculating aquaculture system which consists of fish tanks, screen filter, biological filter, oxygen generator, oxygen maxing and hydroponic units.

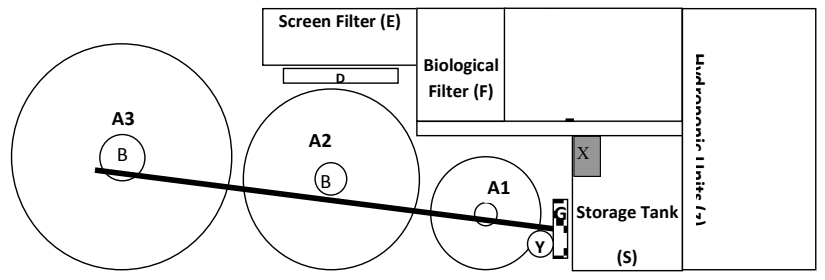

Figure 1: Fish tank, A; particle trap, B; channel collector, D; screen filter, $E$ biological filter, F; storage tank, S; pumps, G; heat exchanger, X; Downflow oxygen contactor, Y; Hydroponic units, $Z$.

*Corresponding author: El-Sayed G. Khater, Agricultural Engineering Department - Faculty of Agriculture - Benha University 13736, Egypt, Tel: +20132467034 E-mail: alsayed.khater@fagr.bu.edu.eg

Received December 22, 2014; Accepted January 19, 2015; Published February 15,2015

Citation: Khater ESG, Ali SA (2015) Effect of Flow Rate and Length of Gully on Lettuce Plants in Aquaponic and Hydroponic Systems. J Aquac Res Development 6: 318. doi:10.4172/2155-9546.1000318

Copyright: (c) 2015 Khater ESG, et al. This is an open-access article distributed under the terms of the Creative Commons Attribution License, which permits unrestricted use, distribution, and reproduction in any medium, provided the original author and source are credited. 
The system consists of three circular concrete tanks were used for fish culture. Dimensions of tanks are ( $5 \mathrm{~m}$ diameter $\mathrm{x} 1.25 \mathrm{~m}$ height), (8 $\mathrm{m}$ diameter $\mathrm{x} 1.25 \mathrm{~m}$ height), and (10 m diameter $\mathrm{x} 1.25 \mathrm{~m}$ height). The water volumes used in tanks were 25,50 , and $100 \mathrm{~m}^{3}$ respectively. Each tank was provide to a particle trap in the center for water drain waste solids, settleable solids flow under a plate, in a flow of water that amounts to only 5 percent of the total flow leaving the center of the tank. The larger flow (95 percent of the total) exits the tank through a larger discharge strainer mounted at the top of the particle trap.

The drum screen filter used in this system which has dimensions was $1.7 \mathrm{~m}$ in diameter and $2.0 \mathrm{~m}$ long. The filter was made from stainless steel at private company for steel industry. The fine mesh silk 60 micron was used a media of screening.

Rotating Biological Contactor (RBC) used in this system, has 1.5 $\mathrm{m}$ in diameter and $2.0 \mathrm{~m}$ long. The filter was made from stainless steel. Used polyethylene tubes were used as a media. The filter was driven by one motor of $1.5 \mathrm{~kW}$ power and $1500 \mathrm{rpm}$ and a gearbox to reduce the speed 500 times to give the recommended rotating speed $(3 \mathrm{rpm})$.

Pure oxygen used in this system source of oxygen gas was oxygen generator. Adding pure oxygen gas to water by oxygen mixer. The water and oxygen enter the top of the oxygen mixer, as the water and oxygen move downward.

The hydroponic units (NFT) in this study consisted of two sources of nutrient solution were used (1) Stock nutrient solution and (2) Effluent fish farm, three lengths of gully (2, 3 and $4 \mathrm{~m})$ and three water flow rates $1,1.5$ and $2 \mathrm{~L} \mathrm{~min}^{-1}$. Intermitted flow (1 minute 'on' and 4 minute 'off') as described by [17].

Figure 2 shows the design of hydroponic units. The gullies were $50 \mathrm{~cm}$ wide, slope $2 \%$ and stand $1 \mathrm{~m}$ high above the ground with row spacing of $20 \mathrm{~cm}$. The gullies frames were made from iron, lined by plastic sheet and covered with foam boards to support the plants.

The solution was pumped from the tank to the upper ends of the gullies. Small tubes were used to supply each gully by nutrient solution or effluent fish farm. Nutrient solution is circulated in closed system. The tank of the nutrient solution system with a capacity of 200 liter capacity was used for collecting the drained solution by gravity from the ends of the gullies. The nutrient solutions were prepared manually once per ten days dissolving appropriate amounts of $\mathrm{Ca}\left(\mathrm{NO}_{3}\right)_{2}, \mathrm{KNO}_{3}$ $\mathrm{K}_{2} \mathrm{SO}_{4}, \mathrm{KH}_{2} \mathrm{PO}_{4}, \mathrm{MgSO}_{4}$ and chelates for trace elements into preacidified groundwater, $\mathrm{pH}$ was further adjusted to 6.0-7.0 after salt addition.

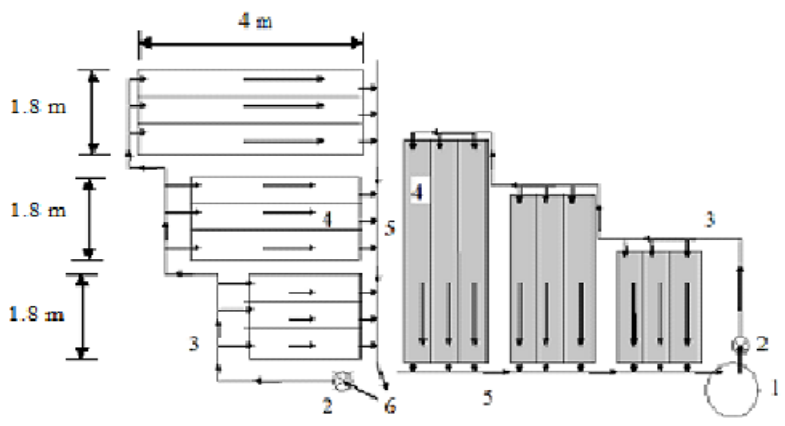

Figure 2:Layout of the experiment setup. Solution tank, 1; Pump, 2; Flow pipe, 3; Gullies, 4; Catchment pipe, 5; Water farm, 6; $\square$ Nutrient solution $\square$ Effluent fish water.

\section{Lettuce germination}

Lettuce seeds (Romein type) were sown in the plastic cups $(5 \mathrm{~cm}$ diameter and $5 \mathrm{~cm}$ height) filled with peatmoss. The cups were watered daily using water with nutrient solution. Three weeks old lettuce seedlings were planted in the experimental trays [18].

\section{Measurements}

Water samples were taken, at inlet and outlet of the hydroponic units for measured Ammonia $\left(\mathrm{NH}_{3}\right)$, Nitrite $\left(\mathrm{NO}_{2}\right)$, Nitrate $\left(\mathrm{NO}_{3}\right)$, Phosphorus (P), Potassium (K), Calcium (Ca) and Magnesium (Mg). Ammonia $\left(\mathrm{NH}_{3}\right)$, Nitrite $\left(\mathrm{NO}_{2}\right)$, Nitrate $\left(\mathrm{NO}_{3}\right)$ and Phosphorus (P) measured by a Spekol 11 (Model SPEKOL 11-Range 0.1-1000 concentration $\pm 1 \mathrm{~nm} \lambda$, UK). Potassium (K) measured by flame photometer (Model Jenway PFP7-Range 0.1-999.9 ppm $\pm 0.2 \mathrm{ppm}$, USA). Calcium (Ca) and Magnesium (Mg) measured by using disodium versenate method as described by [19]. The dry weight was measured at the end of the experiment. After measured fresh weight the plants were oven dried at $70^{\circ} \mathrm{C}$ until constant weight was reached. The $\mathrm{NO}_{3}-\mathrm{N}$ content was evaluated after being digested. Nitrate $\left(\mathrm{NO}_{3}-\mathrm{N}\right)$ content was measured by using salsalic acid as described by [20].

\section{Statistical analysis}

The statistical analysis for the data obtained was done according to [21] and the treatments were compared using Least Significant Differences (LSD) test at 99\% confidence level [22].

\section{Results and Discussion}

\section{Nutrients uptake}

Any removal of nutrients from the solution can be equated with uptake by plants, provided that the system is free from leaks, algae and regardless of precipitation. Figures $3 \mathrm{a}-3 \mathrm{e}$ show $\mathrm{N}, \mathrm{P}, \mathrm{K}, \mathrm{Ca}$ and $\mathrm{Mg}$ uptake by lettuce plants at the end of the growing period. The nutrients uptakes were significantly increased in nutrient solution over those of effluent fish water. The N, P, K, Ca and Mg uptakes were 300.46, 69.01, $434.86,153.66$ and $254.78 \mathrm{mg} \mathrm{plant}^{-1}$, respectively in nutrient solution

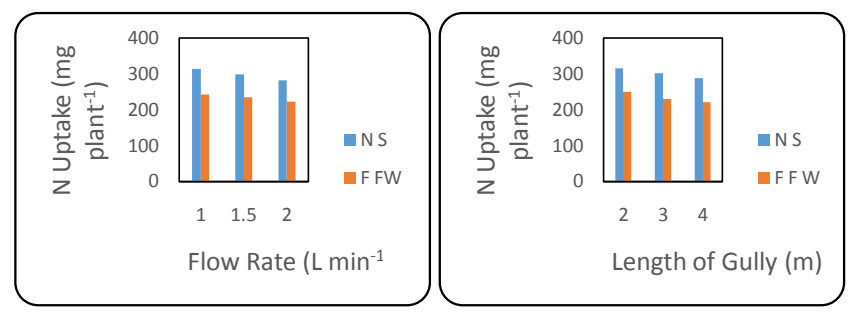

Figure 3a: $\mathrm{N}$ uptake by lettuce plants at the end of the growing period.
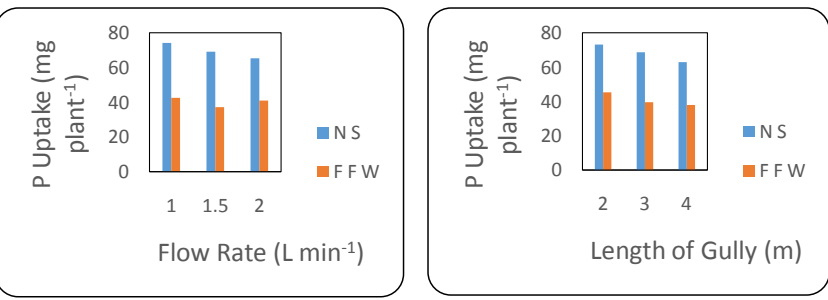

Figure 3b: $\mathrm{P}$ uptake by lettuce plants at the end of the growing period. 


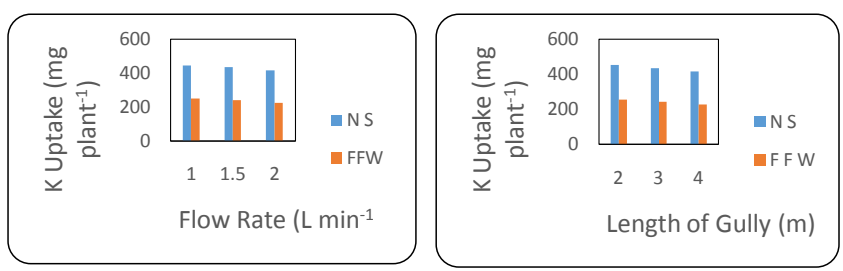

Figure 3c: K uptake by lettuce plants at the end of the growing period.

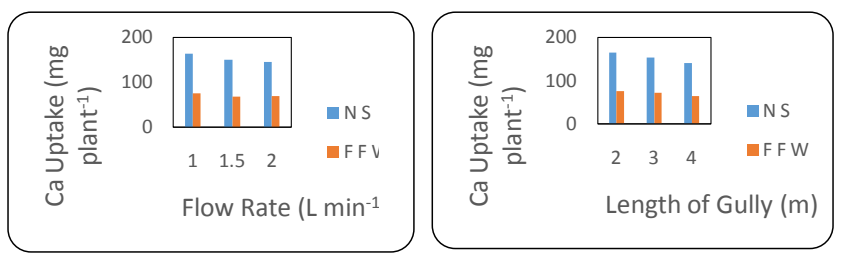

Figure 3d: Ca uptake by lettuce plants at the end of the growing period.

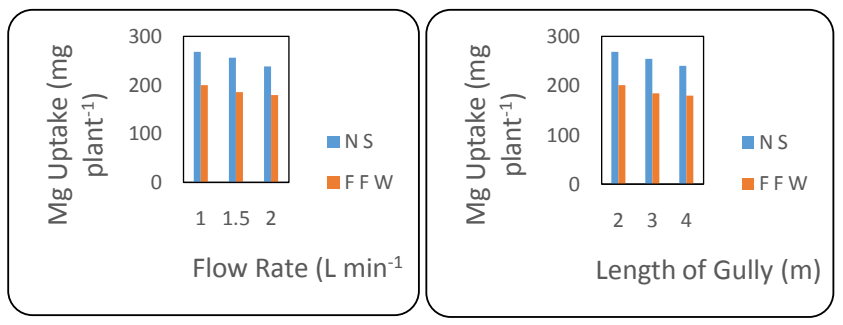

Figure 3e: Mg uptake by lettuce plants at the end of the growing period.

and the N, P, K, Ca and Mg uptakes were 233.73, 40.70, 241.34, 71.08 and $188.78 \mathrm{mg} \mathrm{plant}^{-1}$, respectively in effluent fish water. The nutrients uptakes were decreased with increasing the flow rate and length of gully. $\mathrm{N}$ uptake significantly decreased from 316.22 to $282.62 \mathrm{mg} \mathrm{plant}^{-1}$ (10.63\%) in nutrient solution and significantly decreased from 242.78 to $222.72 \mathrm{mg} \mathrm{plant}^{-1}(8.26 \%)$ in effluent fish water at 1 and $2 \mathrm{~L} \mathrm{~min}^{-1}$ flow rate, respectively. $\mathrm{N}$ uptake significantly decreased from 316.22 to $288.48 \mathrm{mg}$ plant $^{-1}(8.77 \%)$ in nutrient solution and significantly decreased from 250.18 to $221.95 \mathrm{mg}$ plant $^{-1}$ (11.28\%) in effluent fish water at 2 and $4 \mathrm{~m}$ length of gully, respectively.

$\mathrm{P}$ uptake significantly decreased from 74.21 to $65.47 \mathrm{mg}$ plant $^{-1}$ (11.78\%) in nutrient solution and significantly decreased from 42.62 to $41.09 \mathrm{mg} \mathrm{plant}^{-1}$ (3.59\%) in effluent fish water at 1 and $2 \mathrm{~L} \mathrm{~min}^{-1}$ flow rate, respectively. P uptake significantly decreased from 73.34 to 63.17 $\mathrm{mg}$ plant $^{-1}(13.87 \%)$ in nutrient solution and significantly decreased from 45.31 to $38.21 \mathrm{mg} \mathrm{plant}^{-1}(15.70 \%)$ in effluent fish water at 2 and 4 $\mathrm{m}$ length of gully, respectively.

K uptake significantly decreased from 444.58 to $416.16 \mathrm{mg} \mathrm{plant}^{-1}$ (6.39\%) in nutrient solution and significantly decreased from 250.46 to $225.98 \mathrm{mg}_{\text {plant }}{ }^{-1}(9.77 \%)$ in effluent fish water at 1 and $2 \mathrm{~L} \mathrm{~min}$ ${ }^{1}$ flow rate, respectively. K uptake significantly decreased from 456.00 to $418.37 \mathrm{mg}$ plant $^{-1}(8.25 \%)$ in nutrient solution and significantly decreased from 258.14 to $228.29 \mathrm{mg}$ plant $^{-1}$ (11.56\%) in effluent fish water at 2 and $4 \mathrm{~m}$ length of gully, respectively.

Ca uptake significantly decreased from 164.06 to $145.80 \mathrm{mg} \mathrm{plant}^{-1}$
(11.13\%) in nutrient solution and significantly decreased from 76.51 to $70.04 \mathrm{mg}$ plant $^{-1}(8.46 \%)$ in effluent fish water at 1 and $2 \mathrm{~L} \mathrm{~min}^{-1}$ flow rate, respectively. Ca uptake significantly decreased from 165.70 to $141.51 \mathrm{mg}$ plant $^{-1}(19.59 \%)$ in nutrient solution and significantly decreased from 75.84 to $63.71 \mathrm{mg}$ plant $^{-1}(14.04 \%)$ in effluent fish water at 2 and $4 \mathrm{~m}$ length of gully, respectively.

Mg uptake significantly decreased from 268.72 to $238.91 \mathrm{mg} \mathrm{plant}^{-1}$ (11.09\%) in nutrient solution and significantly decreased from 200.22 to $179.97 \mathrm{mg}$ plant $^{-1}(10.11 \%)$ in effluent fish water at 1 and $2 \mathrm{~L} \mathrm{~min}^{-1}$ flow rate, respectively. Mg uptake significantly decreased from 268.99 to $240.68 \mathrm{mg} \mathrm{plant}^{-1}(10.52 \%)$ in nutrient solution and significantly decreased from 201.70 to $179.68 \mathrm{mg}$ plant $^{-1}$ (10.92\%) in effluent fish farm at 2 and $4 \mathrm{~m}$ length of gully, respectively.

The lowest values of plant consumption were found in treatment of effluent fish water at a flow rate of $2 \mathrm{~L} \mathrm{~min}^{-1}$ with length of gully $4 \mathrm{~m}$ and the highest values were recorded at a flow rate of $1 \mathrm{~L} \mathrm{~min}^{-1}$ with length of gully $2 \mathrm{~m}$. Increasing the velocity of water in gullies with increasing the flow rate decreased the rate of nutrient consumption. These results agreed with those obtained by [23-25].

The lowest values of plant consumption were found at $4 \mathrm{~m}$ length of gully and the highest values were found at $2 \mathrm{~m}$ length of gully. This may be due to the number of plants in case of $4 \mathrm{~m}$ length as compared with those of $2 \mathrm{~m}$ length. Worthy to note that pumping either nutrient solution or effluent fish water to the growing gullies was adjusted at 1 min pumping and $4 \mathrm{~m}$ rest. This was performed with 1.0, 1.5 and $2 \mathrm{~L}$ $\mathrm{min}^{-1}$ discharge in 2, 3 and $4 \mathrm{~m}$ of the gullies. Thus, the nutrient stayed longer under the $4 \mathrm{~m}$ length and the total intake periods of nutrients were longer than those achieved with the shorter gullies $(2 \mathrm{~m})$. The refreshment of nutrients under the longer gullies were restricted as compared with the shorter ones. These results agreed with those obtained by [26].

\section{Fresh and dry weight}

Fresh and dry weight of shoots: Figures $4 \mathrm{a}$ and $4 \mathrm{~b}$ show the effect of source of nutrients, flow rates and lengths of gully on the fresh and dry weights production of lettuce plants at the end of growing period. The fresh and dry weights of shoots w significantly increased in nutrient solution over those of effluent fish water. The fresh weights of shoots were 207.12 and $190.32 \mathrm{~g} \mathrm{plant}^{-1}$ for nutrient solution and effluent fish water, respectively. The dry weights of shoots were 21.34 and $19.74 \mathrm{~g}$
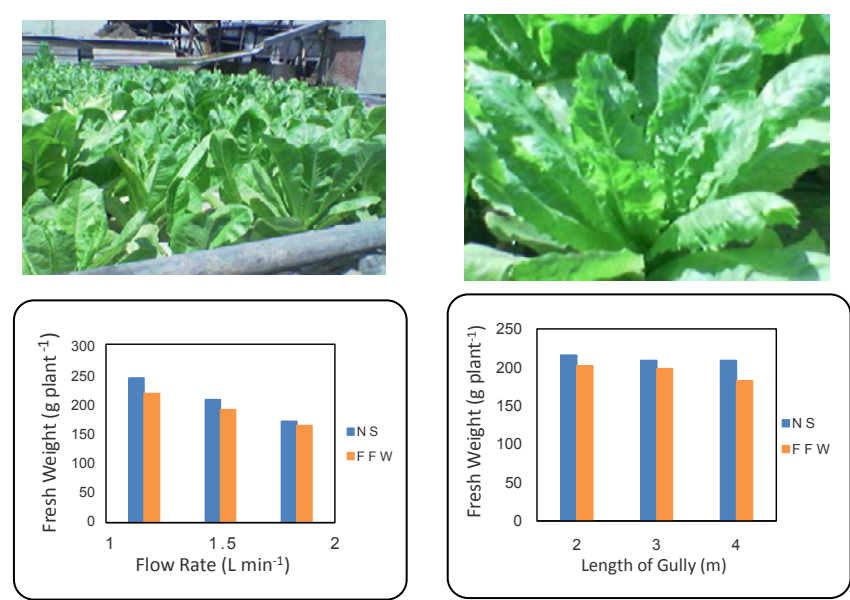

Figure 4a: Fresh weight of shoots at the end of the growing period. 

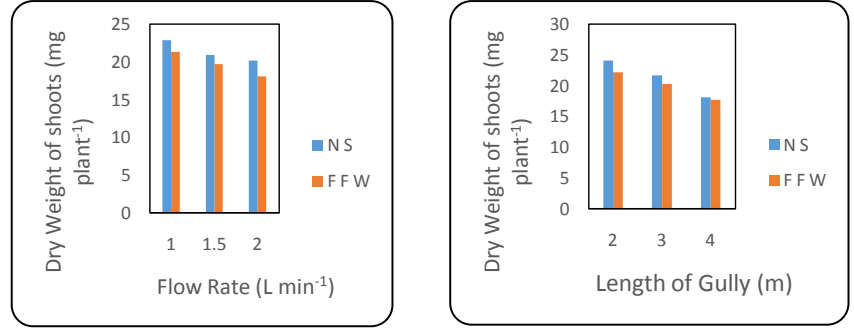

Figure 4b: Dry weight of shoots at the end of the growing period.
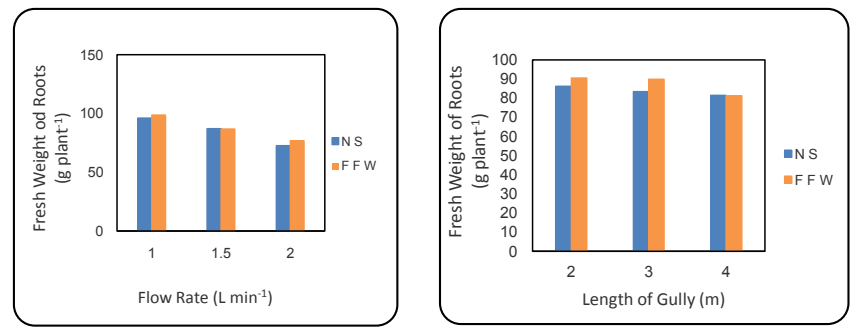

Figure 5a: Fresh weight of roots at the end of the growing period.
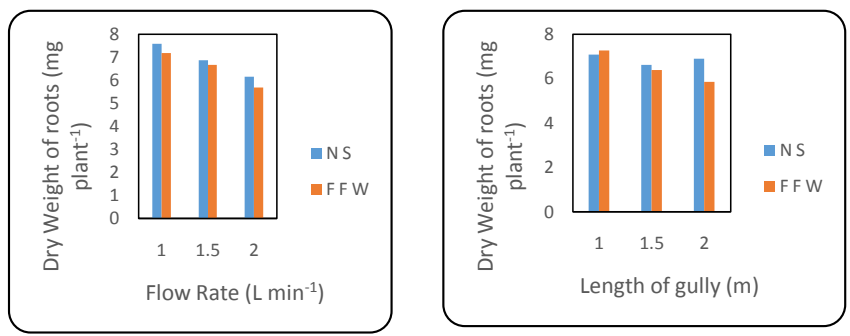

Figure 5b: Dry weight of roots at the end of the growing period.

plant $^{-1}$ for nutrient solution and effluent fish water, respectively. The highest value of fresh and dry weights of 215.88 and 26.36 g plant $^{-1}$ was obtained with a flow rate of $1.0 \mathrm{~L} \mathrm{~min}^{-1}$ and $2 \mathrm{~m}$ length of gully, while, the lowest value of fresh and dry weights of 170.68 and $19.05 \mathrm{~g}$ plant ${ }^{-1}$ occurred at a flow rate of $1.5 \mathrm{~L} \mathrm{~min}^{-1}$ and $4 \mathrm{~m}$ length of gully in nutrient solution. On the other hand, the highest value of fresh and dry weights of 217.18 and 23.72 g plant $^{-1}$ was obtained at a flow rate of 1.0 $\mathrm{L} \mathrm{min}^{-1}$ with $2 \mathrm{~m}$ length of gully, while, the lowest value of fresh and dry weights 163.46 and 15.99 g plant $^{-1}$ was obtained at a flow rate of $2.0 \mathrm{~L}$ $\mathrm{min}^{-1}$ with $4 \mathrm{~m}$ length of gully in effluent fish water.

Decreasing the fresh and dry weights of shoots with increasing the flow rate from 1 to $2 \mathrm{~L} \mathrm{~min}^{-1}$ and increased the length of gully from 2 to $4 \mathrm{~m}$ may be attributed to decrease in nutrient consumption rate. These results agreed with those obtained by [27] who found that the dry weight decreased with increasing the flow rate from 0.5 to $1.5 \mathrm{~L} \mathrm{hour}^{-1}$.

\section{Fresh and dry weight of roots}

Figures $5 \mathrm{a}$ and $5 \mathrm{~b}$ show the fresh and dry weights of roots production of lettuce plants at the end of growing period ( 50 days). The fresh and dry weights of roots were significantly increased in nutrient solution over those of effluent fish water. The fresh and weight of roots was 83.70 and
$87.29 \mathrm{~g} \mathrm{plant}^{-1}$ for nutrient solution and effluent fish water, respectively. The fresh and dry weights of roots were 6.89 and $6.52 \mathrm{~g} \mathrm{plant}^{-1}$ for nutrient solution and effluent fish water, respectively. The fresh and dry weights were decreased with increased the flow rate and length of gully. The fresh and dry weights significantly decreased from 96.13 to 72.51 g plant $^{-1}(24.57 \%)$ and 7.59 to 6.17 g plant $^{-1}(18.71 \%)$, respectively, in nutrient solution and significantly decreased from 98.46 to $76.68 \mathrm{~g}$ plant $^{-1}(22.12 \%)$ and 7.20 to 5.69 g plant $^{-1}(20.20 \%)$, respectively, in effluent fish water at 1 and $2 \mathrm{~L} \mathrm{~min}^{-1}$ flow rate, respectively. The fresh and dry weights significantly decreased from 86.13 to $81.55 \mathrm{~g} \mathrm{plant}^{-1}$ $(5.32 \%)$ and 7.10 to 6.92 g plant $^{-1}(25.35 \%)$, respectively, in nutrient solution and significantly decreased from 90.57 to $81.32 \mathrm{~g} \mathrm{plant}^{-1}$ (10.21\%) and 7.29 to 5.87 g plant $^{-1}(19.48 \%)$, respectively, in effluent fish water at 2 and $4 \mathrm{~m}$ length of gullies, respectively.

Decreasing the fresh and dry weights of roots with increasing the flow rate from 1 to $2 \mathrm{~L} \mathrm{~min}^{-1}$ and increasing the length of gully from 2 to $4 \mathrm{~m}$ may be attributed to decrease in nutrient consumption rate.

Furthermore, the fresh and dry weights of roots were higher in nutrient solution than in effluent fish water. This helps to explain differences yield and growth of root in between various solutions. Generally, Nutrient solution has provided optimum conditions to the root system of the plant with regard to the amount of nutrients available to the roots and their balance in addition to sufficient, oxygen supply, the appropriate osmotic pressure of solution and its temperature. These results agreed with those obtained by [26].

\section{$\mathrm{No}_{3}-\mathrm{N}$ content in plant}

Figure 6 shows the $\mathrm{No}_{3}-\mathrm{N}$ content by lettuce plants at the end of the growing period as estimated from the dry weight of the entire plant and nutrient concentration. The $\mathrm{No}_{3}-\mathrm{N}$ content was significantly increased in nutrient solution over those of effluent fish water. The $\mathrm{No}_{3}-\mathrm{N}$ content was 227.23 and $107.81 \mathrm{~g} \mathrm{plant}^{-1}$ for nutrient solution and effluent fish water, respectively. The $\mathrm{No}_{3}-\mathrm{N}$ content was decreased with increasing the flow rate and length of gully. The $\mathrm{No}_{3}-\mathrm{N}$ content significantly decreased from 241.07 to $208.62 \mathrm{mg}$ plant $^{-1}(13.46 \%)$ in nutrient solution and significantly decreased from 113.55 to 96.74 mg plant ${ }^{-1}(14.80 \%)$ in effluent fish farm at 1 and $2 \mathrm{~L} \mathrm{~min}^{-1}$ flow rate, respectively. The $\mathrm{No}_{3}-\mathrm{N}$ content significantly decreased from 245.82 to $212.05 \mathrm{mg}^{-1 a n t^{-1}}$ (13.74\%) in nutrient solution and significantly decreased from 115.66 to $103.17 \mathrm{mg}$ plant $^{-1}(10.80 \%)$ in effluent fish farm at 2 and $4 \mathrm{~m}$ length of gully, respectively.

That is to say, $\mathrm{No}_{3}-\mathrm{N}$ content in plants grown in nutrient solution was almost 2 times of that in those grown in effluent fish water. This may be due to high concentrations of nutrient solution as compared with those of effluent fish farm.
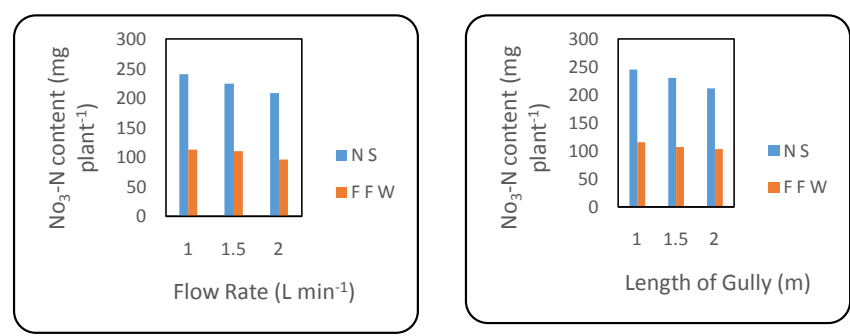

Figure 6: $\mathrm{No}_{3}-\mathrm{Ncontent}$ in plant at the end of the growing period. 
Citation: Khater ESG, Ali SA (2015) Effect of Flow Rate and Length of Gully on Lettuce Plants in Aquaponic and Hydroponic Systems. J Aquac Res Development 6: 318. doi:10.4172/2155-9546.1000318

Page 5 of 5

\section{Conclusions}

The experiment was carried out to study the effect of source of nutrient, flow rate and length of gully on the following parameters: nutrients uptake, dry weight of shoots and roots and $\mathrm{No}_{3}-\mathrm{N}$ content in plant. The treatments under study are: source of nutrient (waste fish farm and stock nutrient solution), flow rate $(1.0,1.5$ and $2.0 \mathrm{~L}$ $\left.\mathrm{min}^{-1}\right)$ and length of gully $(2,3$ and $4 \mathrm{~m})$. The obtained results can be summarized as follows:

- The nutrients uptakes were decreased with increasing the flow rate and the length of gully. The total nutrients uptake values were higher in nutrient solution than those in effluent fish water.

- The fresh weight of shoots and roots were decreased with increasing the flow rate and the length of gully. The fresh weight of shoots was higher in nutrient solution than in effluent fish water by $8.09 \%$.

- The dry weight of shoots and roots were decreased with increasing the flow rate and the length of gully. The dry weight of shoots and roots were higher in nutrient solution than in effluent fish water by 11.64 and $6.68 \%$, respectively.

- The $\mathrm{NO}_{3}-\mathrm{N}$ content was decreased with increasing the flow rate and the length of gully. The $\mathrm{NO}_{3}-\mathrm{N}$ content was higher in plants grown in nutrient solution than those of plants grown in effluent fish water by $110.79 \%$.

The best flow rate for $2 \mathrm{~m}$ length of gully was $1.5 \mathrm{~L} \mathrm{~min}^{-1}$, the best flow rate for $3 \mathrm{~m}$ length of gully was $1.5 \mathrm{~L} \mathrm{~min}^{-1}$ and the best flow rate for $4 \mathrm{~m}$ length of gully was $2 \mathrm{~L} \mathrm{~min}^{-1}$.

It could be concluded that aquaponic system is one of the economical solutions for getting benefits from the water-waste from the fish farms as it save nutrients and produce fresh vegetables, i.e., lettuce. With using this system successively its cost will be decreased and became more economic. The produced plants via this system considered as an organic product which is more safe for human consumption.

\section{References}

1. Johnson DM, Wardlow GW (1997) A prototype recirculating aquaculturehydroponic system.

2. Diver S (2000) Aquaponics-integration of hydroponics with aquaculture.

3. Bromes B (2002) Aquaponics.

4. Rakocy JE (2002) Aquaponics: vegetable hydroponics in recirculating systems

5. Selock D (2003) An introduction to aquaponics: the symbiotic culture of fish and plants.

6. Lee CS (2004) Aquaponics, An integrated fish culture and vegetable hydroponics production system.

7. Okimoto DK (2004) Aquaponics export conducts workshops in American Samoa
8. Karen I (2005) Aquaponics from global aquatics turning waste into profits.

9. Nelson RL (2006a) Aquaponics-Hydroponics-Aquaculture.

10. Nelson RL (2006b) Information on aquaponics and aquaculture.

11. Nelson RL (2006c) The source for information on aquaponics and aquaculture

12. Nelson RL (2008) Aquaponic Food Production. Nelson and Pade Inc. Press USA.

13. Graber A, Junge R (2009) Aquaponic systems: nutrient recycling from fish wastewater by vegetable production. Desalination 246: 147-156.

14. Suits B (2010) Access to personal agriculture.

15. Rackocy JE, Hargreaves JA (1993) Integration of vegetable hydroponics with fish culture: a review.

16. Tucker CS, Boyd CE (1985) Water quality, channel catfish culture. Elsevier Sci. Publ. Co., Amesterdam, Netherlands.

17. Benoit F, Ceustermans N (1989) Recommendations for the commercial production of Butterhead lettuce in NFT. Soilless Culture 5: 1-12.

18. Sikawa DC, Yakupitiyage A (2010) The hydroponic production of lettuce (Lactuca sativa L) by using hybrid catfish (Clarias macrocephalus $\times \mathrm{C}$ gariepinus) pond water: Potentials and constraints. Agri Water Manag 97 1317-1325.

19. Black CA (1965) Methods of soil analysis. Part 2, chemical and microbiological properties.

20. Chapman HD, Partt FP (1961) Methods of analysis of soils, plant and water.

21. Snedecor GW, Cochran WG (1980) Statistical methods. Iowa State Univ. Press, Ames, lowa, USA

22. Gomez KA (1984) Statistical procedures for agricultural research. John Wiely and sons, New York, USA

23. Graves CJ, Hurd RG (1983) Intermittent solution circulation in the nutrient film technique. Acta Hort 133: 47-52.

24. Rackocy JE, Hargreaves JA, Bailey DS (1993) Nutrient accumulation in a recirculating aquaculture system integrated with vegetable hydroponic production.American Society of Agricultural Engineering,USA

25. Rackocy JE, Bailey DS, Shultz KA, Cole WM (1997) Evalution of a commercialscale aquaponic unit for the production of tilapia and lettuce. International Symposium on Tilapia in Aquaculture, USA

26. Khater EG (2006) Aquaponics: the integration of fish and vegetable culture in recirculating systems.

27. Fahim MM (1989) Design of nutrient film system for agriculture under greenhouse. 